Proceeding Paper

\title{
Eucalypt Clonal Hybrid Influences the Carbon Amount of Below-Ground Biomass in Oxisol, Brazil ${ }^{+}$
}

\author{
Grasiele Dick ${ }^{1}$, Humberto J. Eufrade-Junior ${ }^{2}$, Mauro V. Schumacher ${ }^{1}$, Gileno B. Azevedo ${ }^{3}$ and \\ Saulo P. S. Guerra 2,*
}

Citation: Dick, G.; Eufrade-Junior, H.J.; Schumacher, M.V.; Azevedo, G.B.; Guerra, S.P.S. Eucalypt Clonal Hybrid Influence the Carbon Amount of Below-Ground Biomass in Oxisol, Brazil. Environ. Sci. Proc. 2021, 3, 53. https://doi.org/10.3390/ IECF2020-07868

Academic Editors: Angela Lo Monaco, Cate Macinnis-Ng and Om P. Rajora

Published: 11 November 2020

Publisher's Note: MDPI stays neutral with regard to jurisdictional claims in published maps and institutional affiliations.

Copyright: (C) 2020 by the authors. Licensee MDPI, Basel, Switzerland. This article is an open access article distributed under the terms and conditions of the Creative Commons Attribution (CC BY) license (http://creativecommons.org/licenses/by/4.0/).
1 Federal University of Santa Maria (UFSM), Santa Maria 97105-900, Brazil; grasidick@hotmail.com (G.K.); mauro.schumacher@ufsm.br (M.V.S.)

2 School of Agricultural Sciences, São Paulo State University (UNESP), Botucatu 18610-034, Brazil; h.eufrade@unesp.br

3 Federal University of Mato Grosso do Sul (UFMS), Chapadão do Sul 79070-900, Brazil; gileno.azevedo@ufms.br

* Correspondence: saulo.guerra@unesp.br

† Presented at the 1st International Electronic Conference on Forests - Forests for a Better Future: Sustainability, Innovation, Interdisciplinarity, 15-30 November 2020; Available online: https://iecf2020.sciforum.net.

\begin{abstract}
The objective of this study was to evaluate whether there is an influence of different clonal hybrids of Eucalyptus urophylla on the carbon concentration and amount in below-ground biomass in trees cultivated in Oxisol, Brazil. Stumps and roots of three different eucalypt hybrid clones, AEC 0144, AEC 0223, and VM01, were selected, weighed immediately after being removed from the ground, and sampled for carbon determination and moisture content at the laboratory. The ShapiroWilk and Bartlett tests were used to evaluate data distribution and the homogeneity of variances, respectively. Analysis of variance (ANOVA) complemented by the Scott-Knott test was used to evaluate the effects of specie/hybrid on the below-ground biomass (dry matter) and carbon amount per stump. The hybrid type of Eucalyptus urophylla does not influence the carbon concentration; however, there is a difference in below-ground biomass production and carbon amount with it being higher for Eucalyptus urophylla $\times$ Eucalyptus camaldulensis when compared to the species Eucalyptus urophylla and hybrid Eucalyptus urophylla $\times$ Eucalyptus grandis.
\end{abstract}

Keywords: stump; root system; bioenergy

\section{Introduction}

In the world, there are about 131 million hectares of plantation forest [1], where 20 million of these are eucalypt plantations [2], with 5.7 million hectares in Brazil [3]. These intensively managed plantations represent $1.5 \%$ of the forested areas of the world, and those destined to forestry with eucalyptus are among the most productive [4].

With the advance of genetic improvement in Brazil since the 1960s, the hybridization technique allowed the improvement of characteristics and expansion of the possibilities of cultivation of Eucalyptus spp., where Eucalyptus urophylla S.T. Blake, due to ecophysiological plasticity, resistance to diseases and productivity, and the possibility of multiple uses of its forest products [5-9]. The hybridization of Eucalyptus urophylla is an option available to wood producers, and they are present across Brazil, especially in the southeast and central west.

The fast growth of Eucalyptus urophylla and its clonal hybrids allows a replacement of genetic material to provide a new generation of seedlings in the market with superior performance. By removing ${ }_{\bar{j}}$ the stumps and coarse roots out of the ground, it is possible to obtain a clean and homogeneous area. These residues have been used as raw material for many purposes, such as cellulose, charcoal, and biomass [10-12]. The purpose of forest 
plantations is not only tied to the production of wood for the generation of energy, pulp, and paper, but also to the function of allocating carbon extracted from the atmosphere used in the metabolic processes of the plant. Carbon (C) is incorporated into the different biomass components above and below ground $[13,14]$, and the accumulated quantity may vary depending on the species/hybrid and age of the tree $[15,16]$. In this sense, forestry emerges as one of the economic activities that are viable alternatives to mitigate the increase in $\mathrm{CO}_{2}$ concentration in the atmosphere [15].

The objective of this study was to evaluate whether there is an influence of different clonal hybrids of Eucalyptus urophylla on the carbon concentration and amount in the below-ground biomass in trees cultivated in Oxisol, Brazil.

\section{Material and Methods}

This study was carried out in Ribas do Rio Pardo, Mato Grosso do Sul state in the

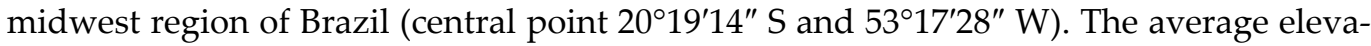
tion is 380 m.a.s.l., the average annual precipitation is $1252 \mathrm{~mm}^{-1} \mathrm{ear}^{-1}$, and the annual average temperature is $24.9^{\circ} \mathrm{C}[17,18]$. The dominant soil was an Oxisol $(2.5 \%$ silt, $13.75 \%$ clay, $83.75 \%$ sand) with $5.1 \mathrm{pH}$ and $4.9 \mathrm{~g} \mathrm{~kg}^{-1}$ of organic matter.

This experiment was conceived and implemented for other academic research [10], being later used for the present study. We analyzed the carbon amount of below-ground biomass from three commercial clones-Eucalyptus urophylla AEC 0144, Eucalyptus urophylla $\times$ Eucalyptus grandis AEC 0224, and Eucalyptus urophylla $\times$ Eucalyptus camaldulensis VM01-, which were described in Table 1.

Table 1. Silvicultural and dendrometric characteristics of the evaluated stands.

\begin{tabular}{lccc}
\hline \multicolumn{1}{c}{ Characteristics } & AEC 0144 & $\begin{array}{c}\text { Clone } \\
\text { AEC 0224 }\end{array}$ & VM01 \\
\hline Stand age (years) & 6.8 & 6.6 & 6.3 \\
DBH $(\mathrm{cm}){ }^{1}$ & $17.8 \pm 2.9$ & $18.8 \pm 3.0$ & $16.7 \pm 2.9$ \\
Height $(\mathrm{m})$ & $23.5 \pm 2.9$ & $24.1 \pm 4.0$ & $19.9 \pm 2.9$ \\
No. stumps per ha & $987.0 \pm 42.0$ & $933.0 \pm 30.0$ & $1049.0 \pm 59.0$ \\
Basal area $\left(\mathrm{m}^{2} \mathrm{ha}^{-1}\right)$ & $25.3 \pm 1.2$ & $26.6 \pm 0.4$ & $23.7 \pm 0.8$ \\
Volume $\left(\mathrm{m}^{3} \mathrm{ha}^{-1}\right)$ & $279.9 \pm 12.1$ & $285.6 \pm 6.1$ & $210.3 \pm 3.5$ \\
Wood basic density $\left(\mathrm{kg} \mathrm{m}^{-3}\right)$ & $410.8 \pm 8.3$ & $444.8 \pm 7.6$ & $495.3 \pm 5.1$ \\
\hline
\end{tabular}

Note: average \pm standard deviation, derived from the measurement of five plots with $500 \mathrm{~m}^{2}$ in each planting. ${ }^{1} \mathrm{DBH}$ : diameter at breast height.

Five plots of $500 \mathrm{~m}^{2}$ were randomly selected for each combination of clone and rotation, totaling 20 plots. In each plot, the diameter at breast height (DBH) and the total height of all trees ( 55 trees per plot) was measured. Thus, twenty-five trees of all diameter classes were sampled and weighted per treatment to evaluate the below-ground biomass.

In the field, the stump and coarse roots were removed with a front-wheel loader simulating a commercial-scale operation commonly used in rural forest areas in Brazil. Thus, this biomass was weighed with a $600 \mathrm{~kg}$ maximum load capacity portable dynamometer (Figure 1). 


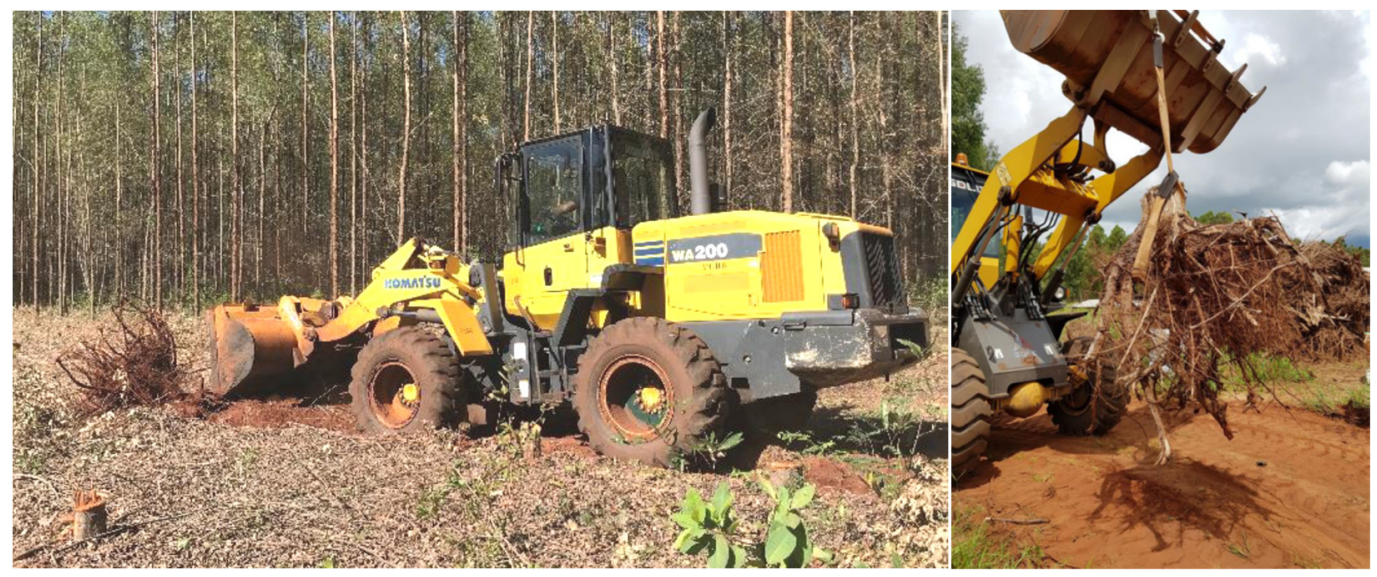

Figure 1. Stumps pulled out of the ground and weighted with a portable dynamometer.

To determine the carbon content only five stumps and coarse roots were used per treatment. Specifically, three different fractions of below-ground biomass were sampled with the support of a chainsaw: 1 . the stump (up to $0.15 \mathrm{~m}$ above the ground); 2 . the upper taproot (mainly represented by the crown root immediately below the surface soil), and 3 . the lower taproot (including the coarse roots, which are those exceeding $5 \mathrm{~mm}$ in diameter [19]).

From the center of each stump region, one $3 \mathrm{~cm}$ thick disk was taken for representative sampling and laboratory analyses. Every disk was divided into quadrants: four similar wedges centered in the medulla of the wood disc. Each quadrant was used to determine the physical and chemical properties.

In the laboratory, the moisture content ( $\mathrm{MC}$ - wet basis) was performed after a complete kiln-dry process in a $105{ }^{\circ} \mathrm{C}$ air-forced oven until constant weight mass, according to ASTM E871-82 [20]. The carbon concentration (C) was obtained using an elemental analyzer, model 2400 Parkin Elmer, using the modified Pregl-Dumas method. The biomass (dry matter) was obtained using the weighted arithmetic average and the moisture content of samples. Thus, the carbon amount of stump biomass was obtained multiplying the biomass with the carbon concentration.

Statistical analysis was performed using [21]. The Shapiro-Wilk and Bartlett tests were used to evaluate data distribution and the homogeneity of variances, respectively. Analysis of variance (ANOVA) complemented by the Scott-Knott test was used to evaluate the effects of specie/hybrid on the below-ground biomass (dry matter) and carbon amount per stump. The results were analyzed with $p<0.05$ representing statistical significance. The clones were close in age, and this effect was not considered in the statistical analysis.

\section{Results}

The carbon concentrations in below-ground biomass do not differ between Eucalyptus urophylla (AEC 0144) and its hybrids; however, there is a more generous amount of biomass produced and, consequently, higher carbon amount in the hybrid Eucalyptus urophylla $\times$ E. camaldulensis (VM01) (Table 2). Both in the species Eucalyptus urophylla and its hybrids, on average, carbon makes up half of the amount of below-ground biomass produced. 
Table 2. Carbon concentration and amount (average \pm standard deviation) of stumps in a hybrid of Eucalyptus urophylla.

\begin{tabular}{lccc}
\hline \multirow{2}{*}{ Clone } & \multirow{2}{*}{$\begin{array}{c}\text { Below-Ground Biomass }{ }^{1} \\
\text { Concentration } \\
(\mathrm{g} \mathrm{kg}-1)\end{array}$} & $\begin{array}{c}\text { Carbon } \\
\text { Amount } \\
(\mathrm{kg} \mathrm{stump}-1)\end{array}$ \\
\hline AEC 0144 & $36.0 \pm 1.6 \mathrm{~b}^{2}$ & $483.5 \pm 0.8 \mathrm{~ns}$ & $17.4 \pm 0.7 \mathrm{c}$ \\
AEC 0224 & $39.3 \pm 0.8 \mathrm{~b}$ & $478.4 \pm 1.3 \mathrm{~ns}$ & $18.8 \pm 0.4 \mathrm{~b}$ \\
VM01 & $41.2 \pm 0.7 \mathrm{a}$ & $485.1 \pm 0.3 \mathrm{~ns}$ & $20.0 \pm 0.3 \mathrm{a}$ \\
\hline
\end{tabular}

${ }^{1}$ Published in [00]; ${ }^{2}$ average values marked by different letters were shown to be significantly different using the Scott-Knott test $(p<0.05) ; \mathrm{ns}=$ non-significant using the $F$ test $(p<0.05)$ in the analysis of variance.

The type of Eucalyptus urophylla hybrid does not influence the carbon concentration; however, there is a difference in the production of below-ground biomass and in carbon amount, which is higher in the trees of the hybrid Eucalyptus urophylla $\times$ E. camaldulensis when compared to the species Eucalyptus urophylla and hybrid Eucalyptus urophylla $\times E$. grandis.

By producing a higher amount of mass with the same carbon concentration observed for the species Eucalyptus urophylla and hybrid Eucalyptus urophylla $\times$ E. grandis, the hybrid Eucalyptus urophylla $\times$ E. camaldulensis is more efficient at below-ground biomass conversion.

\section{Discussion}

Biomass production above and below ground varies according to species and can be influenced, especially by the water and nutritional availability of the site [22]. In the case of the present study, where the trees were cultivated under the same edaphoclimatic conditions, the highest biomass production below the ground of the hybrid Eucalyptus urophylla $\times$ E. camaldulensis occurs mainly due to intrinsic characteristics of this genetic material. One of the factors that results in higher biomass production is wood density, which is higher in the stump and roots of Eucalyptus urophylla $\times$ E. camaldulensis, compared to other clones evaluated (Table 1).

The higher biomass production below the ground of the hybrid Eucalyptus urophylla $x$ E. camaldulensis was not related to higher productivity of the forest settlement (Table 1). The higher biomass production below ground, combined with the lowest productivity, are indicative results that the hybrid Eucalyptus urophylla $\times$ E. camaldulensis may present some limitations concerning the edaphoclimatic conditions of the site, and in addition, the nutritional requirements of this genetic material may not have been fully met. In situations of adequate availability of nutrients in the soil, trees invest more energy for the production of stem wood; on the contrary, the priority is to ensure the survival of the plant, which is promoted by the expansion of the root system [23], consequently, there is an increase in the amount of below-ground biomass and lower productivity.

In comparison with native forest ecosystems, fast-growing eucalyptus stands have a higher proportion of below-ground biomass and carbon, which is necessary for the production and maintenance of roots and mycorrhizas [24]. However, one of the main objectives of forestry is to maximize the production of above-ground biomass, and belowground biomass can act as a carbon stock in the soil in the long term or be used as a bioenergy source, replacing fossil fuels [25]. Waste management should consider several aspects, as stump harvesting affects the carbon stock, which can cause an immediate reduction in the soil $\mathrm{C}$ amount and also increase the $\mathrm{CO}_{2}$ emission of soil organic matter through aeration and exposure of new surfaces [26].

The carbon concentration is directly related to the amount of biomass produced by the trees, representing in this and several studies [13-15,27], on average, half of the structural composition of tree components (leaves, branches, stemwood, stembark, stump, and 
roots). In the present study, there is no variation in the carbon content of stems from $E u$ calyptus urophylla and hybrids (Table 2), as these clones were evaluated at the same age. The age factor of the trees is a determinant for detecting the variation in carbon concentrations in biomass, which are evidenced in evaluations over time [15,16].

On the other hand, the carbon amount determined according to biomass production was influenced by the type of hybrid (Table 2). The hybrid Eucalyptus urophylla $\times$ E. camaldulensis is also more efficient at mitigating atmospheric $\mathrm{CO}_{2}$ emissions, due to the higher allocation of $\mathrm{C}$ in below-ground biomass. Consequently, it will incorporate a more significant amount of organic matter and carbon into the soil after stump and roots decomposition [26].

\section{Conclusions}

The hybrid type of Eucalyptus urophylla does not influence the carbon concentration; however, there is a difference in below-ground biomass production and carbon amount, being higher for Eucalyptus urophylla $\times$ Eucalyptus camaldulensis when compared to the species Eucalyptus urophylla and hybrid Eucalyptus urophylla $\times$ Eucalyptus grandis.

Author Contributions: Conceptualization, G.D. and M.V.S.; methodology, S.P.S.G. and H.J.E.-J.; software, G.B.A.; validation, G.B.A., G.D., and M.V.S.; formal analysis, G.D. and G.B.A.; investigation, G.B.A. and H.J.E.-J.; data curation, H.J.E.-J. and G.B.A.; writing-original draft preparation, G.D. and M.V.S.; writing - review and editing, all; supervision, S.P.S.G. and H.J.E.-J.; project administration, S.P.S.G.; funding acquisition, S.P.S.G. All authors have read and agreed to the published version of the manuscript.

Funding: This research was funded by Âmbar Energia-R\&D ANEEL_Brazilian Electricity Regulatory Agency.

Acknowledgments: The authors would like to acknowledge the Laboratory of Agroforest Biomass and Bioenergy (LABB) at the Institute of Bioenergy Research (IPBEN/UNESP), the Laboratory of Forest Ecology (UFSM), and Grupo Mutum-MS.

Conflicts of Interest: The funders had no role in the design of the study; in the collection, analyses, or interpretation of data; in the writing of the manuscript, or in the decision to publish the results.

\section{References}

1. A Fresh Perspective-Global Forest Resource Assessment 2020. Available online: http://www.fao.org/forest-resources-assessment/2020/en/ (accessed on 5 September 2020).

2. Booth, T.H. Eucalypt plantations and climate change. For. Ecol. Manag. 2013, 301, $28-34$.

3. IBÁ. Relatório Anual 2019. Available online: https://iba.org/datafiles/publicacoes/relatorios/relatorioiba2019-final.pdf (accessed on 1 September 2020).

4. Binkley, D.; Campoe, O.C.; Alvares, C.; Carneiro, R.L.; Cegatta, Í.; Stape, J.L. The interactions of climate, spacing, and genetics on clonal Eucalyptus plantations across Brazil and Uruguay. For. Ecol. Manag. 2017, 405, 271-283.

5. Silva, V.E.; Nogueira, T.A.R.; Abreu-Junior, C.H.; He, Z.; Buzetti, S.; Laclau, J.-P.; Filho, M.C.M.T.; Grilli, E.; Murgia, I.; Capra, G.F. Influences of edaphoclimatic conditions on deep rooting and soil water availability in Brazilian Eucalyptus plantations, For. Ecol. Manag. 2020, 455, 117673.

6. Lu, W.; Arnold, R.J.; Zhang, L.; Luo, J. Genetic Diversity and Structure through Three Cycles of a Eucalyptus urophylla S.T.Blake Breeding Program. Forests 2018, 9, 372.

7. Carignato, A.M.; Cristiano, B.; Zimback, L.; Mori, E.S. Genetic Resistance to Rust of Eucalyptus urophylla Progenies. Floresta e Ambiente 2018, 25, e00094014.

8. Lahr, F.A.R.; Nogueira, M.C.J.A.; Araujo, V.A.; Vasconcelos, J.S.; Christoforo, A.L. Physical-mechanical characterization of Eucalyptus urophylla wood. Eng. Agríc. 2017, 37, 900-906.

9. Azevedo, G.B.; Tomiazzi, H.V.; Azevedo, G.T.D.O.S.; Teodoro, L.P.R.; Teodoro, P.E.; De Souza, M.T.P.; Batista, T.S.; EufradeJunior, H.D.J.; Guerra, S.P.S. Multi-volume modeling of eucalyptus trees using regression and artificial neural networks. PLoS ONE 2020, 15, doi:10.137/journal.pone.0238703.

10. Guerra, S.P.S.; Eufrade-Junior, H.J. Recuperação Energética da Biomassa de Tocos e Raízes de Florestas Plantadas, 1st ed.; FEPAF: Botucatu, Brazil, 2019; pp. 1-186. (In Portuguese)

11. Gominho, J.; Costa, R.A.; Lourenço, A.; Quilhó, T.; Pereira, H. Eucalyptus globulus Stumps Bark: Chemical and Anatomical Characterization under a Valorisation Perspective. Waste Biomass Valorization 2020, 1-13, doi:10.1007/s12649-020-01098-y. 
12. Pimenta, A.S.; da CostaMonteiro, T.V.; Fasciotti, M.; Braga, R.M.; de Souza, E.C.; de Limac, K.M.G. Fast pyrolysis of trunk wood and stump wood from a Brazilian eucalyptus clone. Ind. Crops Prod. 2018, 125, 630-638.

13. Trugilho, P.F.; Arantes, M.D.C.; de Pádua, F.A.; de Paula Almado, R.; Baliza, A.E.R. Estimativa de carbono fixado na madeira de um clone híbrido de Eucalyptus urophylla e Eucalyptus grandis. Cerne 2010, 16, 33-40.

14. Lopes, D.; Aranha, J. Avaliação do conteúdo de carbono na matéria seca de diferentes componentes de árvores de Eucalyptus globulus e de Pinus pinaster. Silva Lusit. 2006, 14, 149-154.

15. Gatto, A.; Barros, N.F.; Novais, R.F.; Silva, I.R.; Leite, H.G.; Villani, E.M.D.A. Estoque de carbono na biomassa de plantações de eucalipto na região centro-leste do estado de Minas Gerais. Rev. Árvore 2011, 35, 895-905.

16. de Assis, M.R.; Trugilho, P.F.; da Silva Rosado, S.C.; de Paula Protasio, T.; Goulart, S.L. Modelagem da biomassa e do estoque de carbono em plantas jovens de Eucalyptus. Sci. For. 2015, 43, 225-233.

17. IBGE. BR Localidades Instituto Brasileiro de Geografia e Estatística. 2010. Available online: ftp://geoftp.ibge.gov.br/organizacao_do_territorio/estrutura_territorial/localidades/Google_KML/BR_Localidades_2010_v1.k $\mathrm{ml}$ (accessed on 3 September 2020).

18. CEMTEC. Banco de Dados ICEMTEC/MS-Semagro. 2018. Available online: http://www.cemtec.ms.gov.br/?page_id=15 (accessed on 30 January 2019).

19. Niiyama, K.; Kajimoto, T.; Matsuura, Y.; Yamashita, T.; Matsuo, N.; Yashiro, Y.; Ripin, A.; Kassim, A.R.; Noor, N.S. Estimation of root biomass based on excavation of individual root systems in a primary dipterocarp forest in Pasoh Forest Reserve, Peninsular Malaysia. Trop. Ecol. 2010, 26, 271-284.

20. ASTM E871-82. Standard Test Method for Moisture Analysis of Particulate Wood Fuels; ASTM International: West Conshohocken, PA, USA, 2006; $2 p$.

21. Ferreira, D.F. Sisvar: A computer statistical analysis system. Ciência e Agrotecnologia 2011, 35, 1039-1042.

22. Stape, J.L.; Binkley, D.; Ryan, M.G. Production and carbon allocation in a clonal Eucalyptus plantation with water and nutrient manipulations. For. Ecol. Manag. 2008, 255, 920-930.

23. Pallardy, S. Physiology of Woody Plants, 3rd ed.; Academic Press: San Diego, CA, USA, 2008; 454p.

24. Giardina, C.P.; Ryan, M.G. Total below-ground carbon allocation in a fast-growing Eucalyptus plantation estimated using a carbon balance approach. Ecosystems 2002, 5, 487-499.

25. Ortiz, C.A.; Hammar, T.; Ahlgren, S.; Hansson, P.A.; Stendahl, J. Time-dependent global warming impact of tree stump bioenergy in Sweden. For. Ecol. Manag. 2016, 371, 5-14.

26. Perrson, T. Environmental consequences of tree-stump harvesting. For. Ecol. Manag. 2013, 290, 1-4.

27. Dick, G.; Schumacher, M.V.; Araújo, E.F. Effect of increasing the fertilizer dose on biomass production of Eucalyptus dunnii Maiden. Floresta 2020, 50, 1353-1362. 